


\title{
First time as a historical driver, second as fantasy: nationalism's Second Coming and the paradoxes of populism ${ }^{1}$
}

\author{
BY: Ulf Hedetoft
}

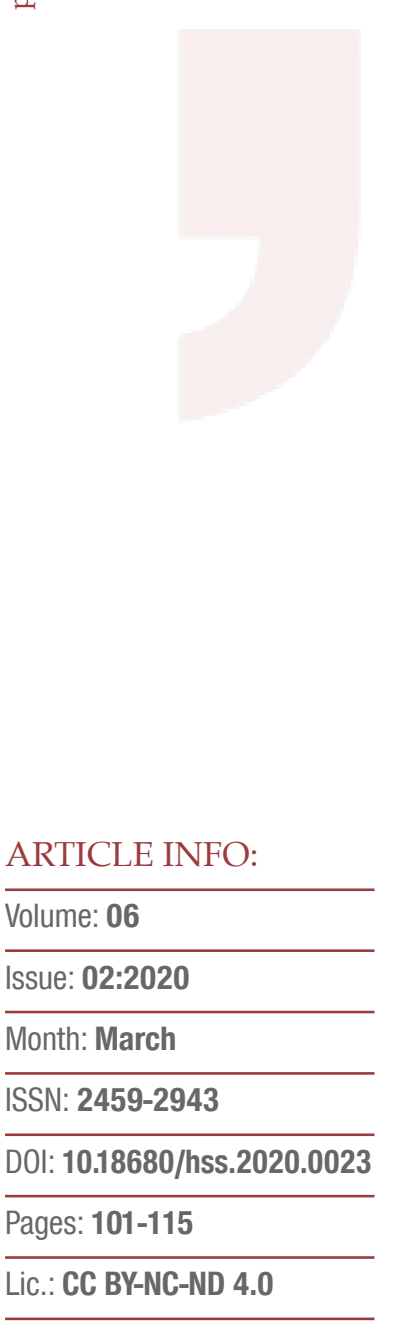

KEYWORDS:

\begin{tabular}{l}
\hline populism \\
\hline the nation-state \\
\hline semiotics \\
\hline symbolism \\
\hline religiosity \\
\hline
\end{tabular}

\section{ABSTRACT}

$\mathrm{N}$ ationalism is a semiotic system in its own right, pivoting around complex dualisms between people and state. Its associated images cover the entire repertoire of signs, from iconicity over indexicalities to symbolism. Nationalism has brought measurable benefits to lots of people; they feel represented by their elected politicians, and they revel in symbolic abstractions of their ethnic-national identity. At least, this is how the national universe has traditionally been configured. Populism, on the other hand, nationalism's recently assumed version, introduces a less materialistic and more fantasy-based approach to national belongingness, reversing some of the national imaginary's ordinary paradoxes. Hence, its sign universe is almost totally dependent on symbols and their arbitrary, nonmotivated connection between signifié and signifiant. This contribution aims to uncover some of the paradoxes manifested by populism and its attempts to reinvest nationalism with former glory while revealing liberalism and globalization as a historical hoax. Populism is a commitment to the idealism of the state while in the same process rejecting its reality. It clings to the formal promise of nationalism without recognizing its contradictory nature. And it refuses to accept that the uniformity of the People conceals a real struggle between groups, generations, regions, and classes in the private sphere - and the multiple challenges to their living standards and welfare that provided the origins of their populist reaction. Populism sends its supporters back to where they came from, but with a vengeance.

\footnotetext{
${ }^{1}$ This article is an expanded and re-worked version of chapter 5 in my monograph, Paradoxes of Populism. Troubles of the West and Nationalism's Second Coming (Hedetoft 2020).
} 


\section{Introduction}

In an important sense, nationalism is a semiotic system in its own right. It pivots around complex dualisms between people and state, material interests and cultural belonging, diversity, and uniformity, 'we' and 'they,' hostility and collaboration, pride and shame, historical realities and mythical inventions, banalities and lofty ideas, collectivism and individualism, concreteness and abstraction (Anderson 1983; Billig 1995; Gellner 1983; Hedetoft 1995; Hobsbawn \& Ranger 1983). As a historical force, it contains all of these significations while assuming the role both of a forward-looking, progressive modernizer, which liberated scores of ordinary people from thraldom and oppression, and a violent and often brutal eliminator of traditions, cultures, human beings, and occasionally entire regimes. The paradox is manifested in its creation of, on the one hand, welfare states with relatively high levels of prosperity for the majority of citizens, and, on the other, the brutality of fascism and its authoritarian oppression of its own people as well as its raid on other states. The paradox is inherent in the usual but ideological opposition of 'patriotism' and 'nationalism.' One is hailed as a peaceful, harmless and civilizing force. At the same time, the other is connotatively associated with aggression, belligerence, and warfare. However, the truth is that the terms do not refer to two different realities, but to one and the same, which is constituted inherently of two contradictory components (Hedetoft 1995: 15-19). Nationalism is benevolent and frightening at the same time.

Therefore, its associated images cover the entire repertoire of signs, from iconicity and indexicalities to symbolism (Sebeok 1994: 11). Nationalism has brought measurable benefits to lots of people; they feel represented by their elected politicians, and they revel in symbolic abstractions of their ethnic-national identity. At least, this is how the national universe has traditionally been configured. Populism, on the other hand - the recent version that nationalism has assumed - introduces a less materialistic and more fantasy-based approach to national belongingness and reverses some of the ordinary paradoxes of the national imaginary. Hence, its sign universe is almost totally dependent on symbols and their arbitrary, non-motivated connection between signifie and signifiant. In Peircean terms, the 'object' is either eliminated from the triangulation between sign, interpretant, and object or is totally determined by the sign. ${ }^{2}$

This article aims to uncover some of the 'reverse' (and perverse) paradoxes manifested by populism in all its multiple forms and varieties and highlight its attempt to reinvest nationalism with former glory while revealing liberalism and globalization as a historical hoax created by, and to the sole benefit of, political and economic elites.

\footnotetext{
2 This is most clearly manifested in the disinterest of most populists in the objective relations of the real world, their treatment of fake news (anything that displeases them), their conspiratorial mindset (others have plotted against them), their endless self-victimization and blaming strategies, and the countless promises of the better world that would result if only they had total power. Everything is here dependent on the exclusive power of the sign itself, and the ability / will of the audience to imagine a world decoupled from all the material, economic, social and natural impediments of the real conditions as we know them.
} 


\section{Brexit and the Second Coming of Nationalism}

It is fitting to begin with a lengthy quotation that addresses the Brexit debacle in a way that reveals something fundamental about populism and its inherent paradoxes. In a noteworthy article in The Guardian on 2 December 2018, the newspaper's columnist, Matthew d'Ancona, makes the following comments on the Brexit process - comments that miss the heart of the matter only by an inch.

For decades, there was something close to a political consensus that the most important metric was economic prosperity. A wealthy nation was essential both to the aspirations of individual households and the funding of public services. (...)

Brexit is both symptom and cause of a breakdown in this consensus. It can no longer be taken for granted that senior politicians, or the voters themselves, will automatically and reflexively put national wealth first.

As long ago as January 2014, Nigel Farage was explicit about this: 'If you said to me, would I like to see over the next 10 years a further 5 million people come into Britain and if that happened we'd all be slightly richer, I'd say, I'd rather we weren't slightly richer.' (...)

We have reached the point where, to an extraordinary extent, the implementation of the 2016 referendum result trumps all else. Why so? Because, as Farage declared with more candour than most mainstream politicians can yet muster, culture is nudging old-fashioned political economy out of its prime spot. Immigration is now the gravitational centre of the whole debate: a debate much less about national wealth or national sovereignty than national identity. (...)

We live in a world defined by the economic, social, and cultural interdependence of nation-states. And those who promise that leaving the EU will deliver 'control' are really promising something quite specific: a social and cultural reboot. As well as being morally contemptible, of course, this is also a complete impossibility. [my emphasis].

In this rather remarkable article, which is a lot longer than the above quote, $\mathrm{d}^{\prime}$ Ancona manages to hit several nails on the head and highlight some of populism's crucial features, not just in the UK but universally, in a way that should give us pause. The most obvious point is the one that has to do with the link between economics and identity, wealth and culture. Farage says it clearly and without sugaring the pill: I prefer our identity to economic advantages if that's the choice we have. Rather poorer than subservient, rather sovereign than dependent.

D' Ancona characterizes this stance as impossible and (morally) contemptible, since "[w]e live in a world defined by the economic, social and cultural interdependence of 
nation-states." But whereas he is right about the practical impossibility of realizing the imagined goal of 'taking back control,' he is not spot-on about the morality question per se. Farage and his followers in the Brexit Party at least see the situation differently: in their view, they have taken the moral high ground away from the global opportunists - elites that have filled them with empty promises for years, compromised their trust, and left their British identity by the wayside.

What is decisive about this debate is what they agree on, i.e., that this is a fundamental choice between economics or culture, interest or identity, and that you cannot have your cake and eat it too. The columnist does not directly take a stance on the identity question. Still, it is clearly subordinated to that of wealth, interdependence, and the continued progress of states, in other words to a defense of either Margaret Thatcher's free-market economism or Gordon Brown's concern for the social collectivity - since both relied on the premise of a "strong economy." This has now changed, as d'Ancona is aware: "I think something profound, unsettling but still underexplored, underpins this scale of priorities: a fundamental change that needs to be understood outside the day-to-day disasters of this useless government and even of the Brexit process itself."

He is right. Pitting the economy against national identity questions is unprecedented and has not been considered for well over 150 years. Nevertheless, it is a crucial feature of the populist awakening and an integral part of the semiotics of populism. It is not universally expressed as vigorously and emphatically as does Farage in the quotation, but it applies everywhere. In Trump's policy of slapping China with billions of import duties while simultaneously damaging the US car industry or agriculture. ${ }^{3}$ In the Danish case, where severe restrictions on international students' enrolment and English-language courses reduce the Danish economy's proven benefit from those foreigners who opt to stay after graduating. ${ }^{4} \mathrm{Or}$ in the Hungarian vendetta against Soros and the CEU, which has widespread support but does not in the least take the financial or foreign-policy side-effects into account. ${ }^{5}$

Populists' concern with economic matters and what used to count as the national interest is, if not absent, at least negligible and at best secondary to their national ident-

\footnotetext{
3 One such reaction is the decision by General Motors in November 2018 to lay off several thousands of workers and close down several plants across the USA, which made Trump attack the company, not for faulty economic behavior, but for... ingratitude! (Boudette 2018). In the spring of 2020 the story repeated itself, when Trump ordered GM, among others, to start producing ventilators in the common good in order to battle the coronavirus (Voytko 2020). The moral element of populism is in clear view.

${ }^{4}$ For readers able to read Danish, see https: / / bit.ly / 3blGOrp [Accessed 10 December 2018]. The report concludes that the economic benefits of foreign students (even if many return to their countries after graduation) far outweigh the public costs of enrolling them and (for EU students) paying out the student allowance which is commonly given to Danish students.

5 See e.g. https: / / nyti.ms / 2N9xw9J Accessed 3 December 2018. Interestingly, however, the journalist, Marc Santoro, cites the American ambassador to Hungary as follows: “...in an interview with The Washington Post last week, the ambassador, appointed by President Trump, seemed to react with something of a shrug to the failure to find a solution." Populists support each other against the liberal enemy!
} 
ity's existentialism, ordered national universes, and cultural sovereignty. In the conventional terminology of political science, the economy and the national interest thus interpreted has moved from being the independent to the dependent variable. The pooling of political sovereignty has been overtaken by a uniform insistence on the centrality of cultural sovereignty, the population's ethnic purity, and the intransigence of borders. Nationalism is back, and its symbolic politics has intentionally narrowed down to a limited array of core concerns.

This is the second area where d'Ancona is slightly off the mark. He argues that this is a debate "much less about national wealth or national sovereignty than national identity." However, the fact is that 'sovereignty' has changed places and should now be bracketed with national identity rather than national wealth. Populists are, without exception, sensitive to leaving any part of their national sovereignty in the hands of others or just sharing it with other countries. This is because 'sovereignty' for them has come to signify everything they feel passionately about and cannot abide to see in peril: national history, myths, legends, images, memories, culture, people, borders, wars, and victimization, welfare systems, and all the rest of the 'intergenerational' fabric that enters into all kinds of nationalist phantasmagoria. It has been pulled away from the former primarily legal and political definition and has entered the symbolic realm of identities.

\section{Populism, identity, migrants}

Migrants and foreigners also loom large in d' Ancona's article for a (good) reason. Migrants represent the outside world, which in all populist narratives is surrounded with suspicion, fear, and resentment. They are mobile and can pop up within your borders, they are often visibly foreign, and they give rise to all sorts of negative stereotyping, racist slurs, and defensive-aggressive political action. They are the 'enemy within,' in other words, the object of discrimination and hatred. It's OK to belittle and mock people who do not belong here, who (allegedly) do not contribute, and who should go back where they come from. All this is true - as is the presumption of widespread English racism, however we understand it. Nevertheless, I would argue, the role of migration in the populist imagination is often exaggerated or misrepresented.

First, it is exaggerated because migrants only represent the fundamental issues; they are not their core. Imagine that there were no migrants or threats of immigration. This would not eliminate the inequality problems stemming from the effects of the liberal order, would not keep elites from being labeled as corrupt, and would not prevent the dichotomy between national interest(s) and national identity that we see in the real world. It might help keep ethnic diversity at bay, but that is only a small part of the populist problem. Migration crises trigger a heap of other issues that seem problematic to the populist mind. Still, they do not create the problems, nor do these problems disappear if the migration crisis abates. Hungary and Poland are ruled by populist elites, 
although immigrants' percentage in those countries is negligible. In semiotic terms, the process confuses representation for object.

Secondly, it is misrepresented, not because migration does not enter into the equation, but because the specific reasoning behind what d'Ancona calls the "extremely unpleasant nativism" is not identified correctly. Migrants are not just a sign; in a peculiar way, they are also part of the problem (object). They signify that the political regime has lost control, not merely of national sovereignty, but of the last and most important part of national sovereignty that matters for political elites. The logic runs like this. First, we lose control of our economy and our finances. Then of our ultimate decisionmaking powers, then of our borders, and finally of our popular base, which is or risks being polluted through immigration, diversity, inter-marriage, and multiple citizenships (read: identities). Thus, we lose control of the socialization of 'our people' and, by implication, their undivided loyalty as well. This is both the view of populist ideologues and their supporters' ethnic base, who cherish popular sovereignty and their preferential position therein as much as do political leaders.

However, it also manifests a predicament characterized by a perceived deficiency. It represents the lack of control in the other areas of sovereign existence that migration symbolizes - even when it not (or not yet) in itself a real danger. It, therefore, transposes the problem to other cultural and political domains - e.g., the lack of national control with health, law, housing, crime, finance, labor-market, education, international relations, etc. - calling on populist representatives to tackle the entire sorry state of the nation-state and its identity. Thus, migration comes to occupy the triple role of the sign, object, and representation at the same time. Real problems become mixed and confused with the most unreal fantasies; imagined objectives lead to unimaginable results, and the moralistic vision takes over from hard-nosed analysis.

We are in a sense reminded of Marx' words from On the Jewish Question:

The members of the political state are religious because of the dualism between individual life and species-life, between the life of civil society and political life. They are religious in the sense that man treats political life, which is remote from his own individual existence, as if it were his true life; and in the sense that religion is here the spirit of civil society, and expresses the separation and withdrawal of man from man. Political democracy is Christian in the sense that man, not merely one man but every man, is there considered a sovereign being, a supreme being; but it is uneducated, unsocial man, man just as he is in his fortuitous existence, man as he has been corrupted, lost to himself, alienated, subjected to the rule of inhuman conditions and elements, by the whole organization of our society-in short man who is not yet a real species-being. Creations of fantasy, dreams, the postulates of Christianity, the sovereignty of man-but of man as an alien being distinguished from the real man-all these 
become, in democracy, the tangible and present reality, secular maxims. (Marx 1978 [1843]: 39)

It is Marx with a difference, however. Whereas in the 1843 version, abstract man carries out his political emancipation by subordinating his moral, conscious, but alienated self to his real life as a civil being in the competition between contradictory social actors, the current situation reverses the relationship: the morality of populism aims to take full and complete control of the anarchic person. This is morality carried to its last resort: populists are willing to put their material interests on the back burner if only foreigners and corrupt elites are be quenched, borders fortified, and the pure national home saved.

\section{The general will, moralism and sovereignty}

If this must happen at the expense of democratic processes of the liberal kind, so be it. The result is either 'illiberal democracy' or outright authoritarianism - in both cases with a leadership structure that prioritizes charisma and affective bonding over the logic of economic rationality and clear-cut divisions between 'private' and 'public.' In turn, this implies the religiosity of populism (sometimes with a direct link between Church and State), the widespread embrace of moderation and austerity for the great cause of national belonging, and thus a willing suspension of disbelief. For populists, 'identity' eclipses 'interest,' since the main objective is to safeguard people's continuation and well-being as national citizens with a shared destiny and a common future. According to this way of interpreting the world, nationalism becomes existential, and nation and state fuse into one.

However, measured by the standards of normal nation-state rules and practices, this half-deluded worldview is a step back from the rational advances made by 'modernization. ${ }^{6}$ Why? Mainly because of populism's divisive attachment to a special definition of the constituent people; because of its basic neo-Puritan anti-materialism (despite some discourses to the contrary); and because it compromises the state's function as the institutionalized volonté générale in favor of ruling (or intending to rule) for the 'moral majority' only. Let's look at these arguments in somewhat greater detail.

Populists solve the question of who 'the people' are by nominating a specific part (mostly the select hardworking and nationally minded section, those that globalization has ignored, and those that ideologically represent them) to the status of the whole; the rest is excluded. This interpretation bypasses the legal definition of the people as those who possess formal citizenship and voting rights and instead makes it into a moral question, where those persons and groups that share the policies and preferences of

\footnotetext{
6 This should not be interpreted as identical with the widely held view that populism is a 'distortion' or 'pollution' of democracy (e.g. Müller 2016, Hansen 2017, and many other intellectuals). But it is normally different from the liberal-democratic form of governance, which is undoubtedly its origin of legitimacy.
} 
populists (and at the same time have the right background, origin, and documents) are included. In contrast, the rest are excluded, marginalized, and frequently mocked. ${ }^{7}$ The moral element of being a citizen - universally inherent in the national citizenship notion, which everywhere demarcates citizens from non-citizens, forming the basis of the nation-states' bio-politics - is thus re-interpreted, foregrounded, and prioritized to reinstate the yearned-for unity of people and elites. Or, according to the populist worldview, do away with elites and elevate the People (and their representatives) to the sole sovereignty factor. ${ }^{8}$

The irony is that whereas 'the People' in this sense feel betrayed and abandoned by the liberal/global elites and react loudly and vengefully (Wir sind das Volk!), the 'popular constituent' of sovereignty and its homogeneity of culture is all that these elites have left of their power (see above). The people mandate them (at least the political section), they refer to the people for their legitimacy, they tax the people for their financial resources, and they organize educational activities so that their popular base can represent the nation-state honorably in the global competition for revenue, recognition, and influence. Without the people, they would be nothing. ${ }^{9}$ That is why migration looms so large on national (not just populist) agendas. The suspicion is that migrants (particularly Muslim refugees) cannot be counted on, do not share the secrets of 'our' national culture, have at best divided loyalties, and work against the monocultural ideal, which most politicians in the last resort adhere to. ${ }^{10}$ In a society of 'global

\footnotetext{
7 The most extreme form of an exclusive relationship between political power and a distinct part of the citizenry can be found in Israel, which accepts both Jews and Palestinians as formal citizens, but at the same time insists that the state is only for Jews. This anomaly was legally institutionalized in 2018, see https://bit.ly/3ppV0nT (Agence France-Presse in Jerusalem, 2019). Accessed 11 March 2019. In that light, one might be tempted to nominate Israel to the first place among populist nation-states, had it not been for its democracy, which seems rather frayed and definitely not compatible with democracy elsewhere. Conversely, the two facts may be causally connected.

8 Trump, Orbán, Bolsonaro, Salvini et al are not, in the populist mind, grouped with 'elites' but with 'the people', no matter the wealth they have amassed or the power they possess. They are 'one of us', represent us against the elites 'we' despise and who should be put out of business, prosecuted, and locked up.

9 If the sad corona situation has highlighted nothing else, it has at the very least shown us the desperate dependency of politicians and other elites on their (national) peoples. All the relief packages, all the trillions of dollars expended on the health sectors of different countries, and all the various lockdowns have one thing in common, ie to protect and maintain the 'human factor' of the production process, despite robotics, technological advances, and AI in general. I do not doubt the humane concern of all these policies and the fact that they are also rooted in honest intentions of saving lives and protecting individuals, but they should not and cannot be fully understood in isolation from the perceived cataclysm of imagining the core productivity and growth factor of the economic system being undermined.

10 In an important sense, populist politicians are acting in accordance with Carl Schmitt's views as formulated in the Concept of the Political (CP): "To belong one must identify with the substantive characteristic, whatever it may be, that marks the identity of the people, and one must agree that this characteristic defines a form of life for the preservation of which one ought to be willing to sacrifice one's own life, in the fight against those who don't belong $(\mathrm{CP}, 46)$. (...) Schmitt realizes, of course, that it is possible for people who are not willing to identify in this way to be legally recognized as citizens, and to live law-abidingly, under the norms authorized by some positive constitution. Liberal states, in Schmitt's view, have a tendency to fail to distinguish properly between friends and enemies, and thus to extend rights of membership to those who do not truly belong to the political nation. In a liberal state, Schmitt fears, the political nation will slowly wither and die as a result of spreading de-politicization, it will succumb to internal strife, or it will be overwhelmed by external enemies who are more politically united $(\mathrm{CP}, 69-79)$. To avert these dangers, Schmitt suggests, it is necessary to make sure that the boundaries of the political nation and the boundaries of citizenship coincide." (From The Stanford Encyclopedia of Philosophy 2014, see https: / / stanford.io/2N7YlLh. Accessed 15 December 2018).
} 
diversity,' they would - so goes the populist nightmare - lose not just their primary productive factor but also the cultural cohesion that constitutes most of their remaining sovereignty. They would have only raw power instruments left in their arsenal. They might still have the monopoly of force but can no longer exercise it effectively when power has become externalized from citizens and does not enjoy their backing.

\section{Populism and the victimized People}

These developments are exacerbated by the increasing absence between class origin and party representation, in other words, by the increase in catch-all parties and the competition for votes on an equal footing. All parties address all citizens, not just some particular section of the population. Ideology (and thus the real leadership function of political actors) is scrapped in favor of trying to pander to voter whims. Differences between party programs and policies dwindle, the personal and moral elements of political actors are credited with extra significance, ${ }^{11}$ and it becomes less easy to blame other parties and their politicians for decisions and policies that your own party backs as well. What remains is the narcissism of minor differences. ${ }^{12}$ Instead, domestic battles are externalized, other scapegoats are needed, whether in the form of the EU, uncontrollable influx of 'unassimilable' aliens, or international occurrences beyond national control, like the environmental challenge, international terrorism, or economic downturns.

Such processes open the door to populism, conspiracy theories, and the romanticization of the national past, activating memories of heroism and humiliations, fanning the flames of mistrust in elites and ideas of their betrayal of the real, hardworking, nationally based People: the morally informed victimization and revenge syndrome of populist mentality - and, in the process, emphasize the abnegation of their material desires and support the virulent defense of their national attachment. ${ }^{13}$ Further, it re-introduces signs of political and cultural differences, even oppositions and sometimes contradictions, into a situation otherwise characterized by relative domestic consensus and international wheeling and dealing based on recognizing other state actors in the European and global environment. The declared end-goal of populist policies might be "our nation-state comes first and to hell with the others." Still, the reality of these fundamental changes speaks a different language and leads us in very different directions.

The first part of this 'reality check' is the implications of populism's view of the people as no longer coinciding with all formal citizens. The latter are no longer recog-

11 In the USA, this moralization and personalization of politics is not a new thing whatsoever, which explains why Trumpist populism does not strike the American electorate - unlike the European - as a qualitative departure from mainstream politics, but rather as a gradualist development along a well-known track.

12 A Freudian notion, first found in Civilization and its Discontents (2002: 305). The thesis posits that individuals and cultures closest to each other are also prone to finding and enhancing differences between them.

13 Obviously austerity, self-abnegation, and self-sacrifice have been demanded of citizens all along, also by democratic governments. The novelty is that these 'virtues' are now totally embraced by the populist section of the people as part of their romantic struggle to retain the nation-state framework and its cultural sovereignty intact. 
nized per se as members of the nation-state's moral citizenry. This is far removed from the normal practice in democracies, where governments of different political persuasions come and go, various groups, classes, and regions might benefit slightly from the specific political likes and dislikes of ministers and parties. Still, they all recognize the legitimate existence of the entire electorate, the whole people, and accept the result of elections. Parties that up on the opposition benches, moreover, do their utmost to do their job as opposition properly and gain acknowledgment for precisely that.

Populists, on the other hand, as a rule, do not recognize any opposition when they have gained power and do not recognize governments when they haven't. ${ }^{14}$ In that case, they are branded as corrupt, as traitors, as foreign agents, or just as softies who haven't got the interests of the national population at heart but pursue their selfish concerns, in the process abandoning the people's sovereignty and identity. As pointed out above, a moral definition of the people is superimposed on the legal one, allowing populists - politicians as well as citizens - to apply their moralizing definition and weed out the rotten part of the population, including newcomers with other cultural and ethnic backgrounds, from the 'real People' - the most obvious sign of populism.

The rudeness, lack of ordinary civility, and vengeful behavior of Trump, Orbán, Salvini, Boris Johnson, Marine le Pen, Kaczynski, Wilders, etc., betray this lack of recognition of the domestic Other. It engenders a new kind of political, cultural, and plain human divisions in the national landscape, which cannot be mediated through dialogue and mutual recognition of the opposing side. The differences remain irreparable and potentially produce an unprecedented situation of anarchy, bitterness, and virtual civil war. Eventually, this comes to apply to the liberals too, whose tolerance is tested to its limits and frequently use stereotypes and slurs that compete well with those of the populists. Hillary Clinton's characterization of Trump's supporters as a "basket of deplorables" is only the best known in a long series of abusive, condescending discourses that fail to take the core of the matter into account. Thus, populists, as well as proponents of the liberal-democratic order, are both to blame for the rising chaos and intolerance we face these days, both domestically and in inter-state relations. Liberals and centrists have no reason to be smug. ${ }^{15}$

\footnotetext{
${ }_{14}$ We should, however, admit that this is just the ideal-type and that realities can take a different form. Populist parties in some European countries have come to accept ordinary democratic rules of the game as their route to power, or at the very least profess this to be the case. This would seem to apply to e.g. Denmark, Norway, Finland, Sweden, and Austria.

15 As Bernard Yack correctly points out, "Liberals cannot inoculate themselves against the moral problem with nationalism by adopting a more reasonable understanding of nationhood or a greater appreciation of cultural difference. If they choose to endorse nationalism, then they need to be aware of the need to fight nationalism's corrosive effect on their own moral judgments, not just on the judgements of their more illiberal and irrational rivals" (2012: 232).
} 


\section{The ideal and the reality of populism}

However, what is essential is to see and understand the enormous paradox existing between the ideal and rather idyllic vision of the populist movements, fantasizing about the sovereignty lost and soon to be regained, and the tremendous problems on the ground that their vision in practice engenders. If they accede to power, they do their utmost to shut the opposition out and tamper with fundamental rights, the rule of law, due process, and the division of powers in such a way that it is next to impossible to topple their rule. If they haven't (yet) managed to get that far, they are maniacally occupied with revenge, conspiracy theories, lying, producing fake news - or more subtly with influencing and skewing the political process in their own direction (like in Denmark or Norway, where populism has put on a more democratic garb). They are certainly not concerned about the resentment and disaffection they engender, nor with the destabilization and disruption that inevitably follow in their wake.

The first defect's direct outcome is the second, which, as briefly argued above, represents an instance of severe historical regression. Populists, if not in theory then definitely in practice, reject the line of demarcation between private and public, the sphere of competition and the sphere of the state, between private individuals and citizens and thus also tamper with the legal framework of corporations and public institutions. Fidesz, in its party program, wants to nationalize hitherto privately run health services. Trump treats his office as if he were the CEO of a private company. PiS in Poland works in tandem with the Catholic Church, which as a private denomination has a politicalcum-religious authority comparable to that of the State. Clearly, Berlusconi did not recognize the division but played simultaneously the role as prime minister, company CEO, and owner of the Milan football club without having any qualms about it at all. Matteo Salvini is suspected of having financial and possibly other links to groups in the Italian mafia. ${ }^{16}$ And, most remarkably, none of them recognizes the entirety of their legal citizens as real citizens because they do not enjoy the full backing of all electors and substitute legal reality with moral assessments.

As Timothy Snyder has argued in an article in The New York Times, this is mostly due to the 'personality cult' of the populist (he calls them 'authoritarian') movements. ${ }^{17}$ When everything hangs on one person, his (or her) charisma and his more or less arbitrary assessments, institutions do not matter, nor do accepted lines of division, neutrality, or respect for the 'rules of the game.' Lying, manipulating, and deceiving are OK if it serves a higher purpose. So is self-posturing and self-celebration. For instance, Trump presumes to see through the experts' phony predictions about climate change and rejects a recent climate change report because of his high intelligence! In an interview to the Washington Post, he explains that "one of the problems that a lot of people like my-

\footnotetext{
16 E.g. Tondo and Kirchgaessner 2018. See https:/ / bit.ly/3dfFskm Accessed 6 December 2018.
}

${ }_{17}$ Snyder, The Cowardly Face of Authoritarianism, New York Times, 3 December 2018. 
self have [is that] we have very high levels of intelligence, but we're not necessarily such believers. You look at our air and our water, and it's right now at a record clean" (USA Today, November 27, 2018).

"We're not necessarily such believers" is a revealing comment, representative of the general approach of populist leaders. Amid an assertion based entirely on wishful thinking and airy-fairy postulates about 'intelligence,' Trump manages to turn the entire world upside-down. The statements and predictions of science are made to appear as religious credos, while Trump's amateurish gobbledygook parades as credible and much closer to the truth. This is one of the results of the thoroughgoing personalization of facts that populism represents. But the truth is different and much scarier: it is populism and its charismatic spokespeople who actually stand for a new national order of belief, denial of reality, and myth-making not seen in a long time. Material goals, economic problems, and global challenges seem to disappear but are nevertheless visible in the populist phantasmagoria of national welfare for all, postulates that 'we' are cleaner than ever, and the ever-present threat coming at us from the outside, whether in the form of Russian trolls, Chinese duplicity, North Korean missiles, European federalism, or migrant caravans.

\section{Populism as the religion of nationalism}

Populism is, in this sense, a religion of nationalism pure and simple. Politics has been diminished to a question of believing, not in a god, but a divinely inspired person, who hijacks the religious spirit away from the private realm and catapults it back into the affairs of State. It may be a comfort that, as the US astrophysicist Neil de Grasse Tyson has said, "[t]he good thing about science is that it's true whether or not you believe in it,"18 but it is a question if that is the appropriate answer. 'Normal' democratic politics only takes truth and facts into account under the condition they support specific political goals. ${ }^{19}$ Populism does not care about truth and facts at all, except for discursive purposes. The gap between iconic representation and symbolic signs can no longer be bridged. It has turned into a game of persuading and retaining supporters against their better judgment.

\footnotetext{
18 In Dana Nutticelli, Trump's disbelief won't stop dangerous climate change, The Guardian, 5 December 2018.

19 This is where much talk of a new era of 'post-factualism' errs. Facts and truth have, in democracies, never been respected in their own right, but only in contingent and conditional ways. In this sense, we have been living in 'post-factualism' all our lives. What is new in the populist era is that the conditionality has disappeared and truth has been almost totally replaced by newspeak, fake news and denial of facts. The exception lies in the domains of natural science and technology, because you cannot make robots work, get man on Mars, or create supercomputers by relying on false data and wishful thinking.
} 
We have so far encountered a number of the paradoxes generated by populism in its attempts to find solutions to some of the liberal order's deficiencies and injuries on ordinary people. However, we still need to address the most fundamental paradox, which also explains why populism ends up producing and reproducing the same (or worse) effects, though often in a more affective garb.

This paradox is as evident and banal as it is often overlooked: the unconditional commitment to the nation-state as the ultimate saving grace, the moral foundation, and the sanctuary of nationalism. The departure point was the nation-state's historical formation with all its inherent contradictions and its mix between progressive and destructive elements. This led to the creation of the international order, the recognition of like-minded units in the rest of the world, and finally to several ideologies celebrating pluralism, openness, and a politics of negotiated settlements, which gave greater weight to the material interest component than the spiritual identity element of nationalism. In certain places, most clearly in the EU, it also formally affected the rock bottom of national sovereignty and threatened the state's existential reasoning and its links to its people. Sovereignty developed from an implicit doxa to a pragmatic bargaining chip in political elites' hands, soon to be followed by their financial and commercial counterparts.

There was (and is) a reason for this. The former nation-state compact has gradually become inadequate for representing the interests that the state and its favored private partners need to defend, in the spirit of liberalism and growth. Parts of the old socialnational safety framework need to be sacrificed or downgraded; otherwise, the economy will shrink, 'we' will lose international respect. In the end, citizens will suffer a reduction of salaries and a rollback of national welfare - healthcare, for example. Living standards will, in other words, suffer. Prognoses for the UK post-Brexit order would seem to support this type of conclusion.

Populism's response to this kind of real or projected quandary is, correctly, that the current order is already reducing salaries, producing inequalities, and increasing the workload of ordinary people. Somewhat more doubtfully, populism adds that to avert such unhappy developments, we should return to the pure nation-state condition, forget about international conventions, hold on to 'our' sovereignty at all costs and get our own 'treacherous' elites out of the way to prevent them from harming our identity and cohesion more than they have already done. If, in consequence of all this, there is a slowing of economic growth and income, we should prefer that to the present situation (see Farage, beginning of this article), for we treasure our national identity above all else. 


\section{Conclusion: populism as the collective fantasia of despair}

Thus, the economic rationale of the liberal order encounters a mythological nationalism-cum-religion. However, both take the nation-state as their point of reference and legitimacy. The former because the politicians hail from it and are dependent on it for their popular support, and the populists because they have elevated the People as their savior, and, in the process, semiotically eliminated the distinction between themselves as private individuals and as political actors, trustees of their general will.

This is a commitment to the idealism of the state while in the same process rejecting its reality. It clings to the formal promise of nationalism without recognizing its contradictory nature. And it refuses to accept that the uniformity of 'the People' conceals a real struggle between groups, generations, regions, and classes in the private sphere and the multiple challenges to their living standards and welfare that provided the origins of their populist reaction. Populism sends its supporters back to where they came from, but with a vengeance. Nationalism was once a partly realistic, partly progressive movement, which filled a vital function in civilization's history and the accommodation of contradictory material interests. Now, sadly, it can only be described as a collective fantasia of despair. Any further raids into the semiotics of populism need to be based on this uncomfortable fact.

\section{References}

Agence France-Presse in Jerusalem 2019. Benjamin Netanyahu says Israel is 'not a state of all its citizens.' The Guardian, March 10. See https: / / bit.ly/3ahb0Ex Accessed 11 March 2019.

Anderson, B. 1983. Imagined Communities. London: Verso.

Billig, M. 1995. Banal Nationalism. London: Sage.

Boudette, N. 2018. What's Behind the G.M. Cutbacks, and Why Trump Is Angry. New York Times, 27 November.

d'Ancona, M. 2018. Let's be honest about what's really driving Brexit: bigotry. The Guardian, December 2. See https: / / bit.ly/2N65mMM Accessed 3 December 2018.

DI (Confederation of Danish Industries) 2019. Højtdannede indvandrere er en god forretning for Danmark. Report, December 3. See https: / / bit.ly/3pg59DK Accessed 10 December 2019.

Freud, S. 2002[1929/30]. Civilization and its Discontents [Das Unbehagen in der Kultur]. London: Penguin.

Gellner, E. 1983. Nations and Nationalism. New York: Cornell University Press. 
Hansen, M.H. 2017. Hvordan forvrænger populismen demokratiet? [How does populism distort democracy?] Serien Moderne Tider. Copenhagen: Informations Forlag.

Hedetoft, U. 1995. Signs of Nations. Studies in the Political Semiotics of Self and Other in Contemporary European Nationalism. Aldershot: Dartmouth.

Hedetoft, U. 2020. Paradoxes of Populism. Troubles of the West and Nationalism's Second Coming. New York and London: Anthem Press

Hobsbawm, E. and T. Ranger (eds.) 1983. The Invention of Tradition. Cambridge: Cambridge University Press.

Marx, K. 1978 [1843]. On the Jewish Question. In: Robert Tucker (ed.) The Marx-Engels Reader. New York: Norton \& Company, 26-46.

Müller, J.-W. 2016. What is populism? Philadelphia: University of Pennsylvania Press.

Nutticelli, D. 2018. Trump's disbelief won't stop dangerous climate change. The Guardian, 5 December.

Santora, M. 2018. George Soros-Founded University Is Forced Out of Hungary. New York Times, December 3. See https:/ / nyti.ms/3pjOfpv Accessed 3 December 2018.

Schmitt, C. 2007[1932]. The Concept of the Political. Chicago: University of Chicago Press.

Sebeok, T.A. 1994. An Introduction to Semiotics. London: Pinter.

Snyder, T. 2018. The Cowardly Face of Authoritarianism. New York Times, 3 December. Stanford Encyclopedia of Philosophy 2014. Essay on Carl Schmitt's political philosophy, see https: / / stanford.io/3qlLcNl Accessed 12 December 2018.

Tondo, L. and S. Kirchgaessner 2018. Matteo Salvini backed by politician with 'links to mafia.' The Guardian, July 3. See https: / / bit.ly / 3jOxT5r Accessed 6 December 2018.

Voytko, L. 2020. Trump Orders GM To Make Ventilators - 10 Days After Company Says It Started Making Them. Forbes, 30 March.

Yack, B. 2012. Nationalism and the Moral Psychology of Community. Chicago and London: University of Chicago Press.

AUTHOR

Ulf Hedetoft Professor of International Studies, Saxo Institute, University of Copenhagen, and Director, Center for the Study of Nationalism. 


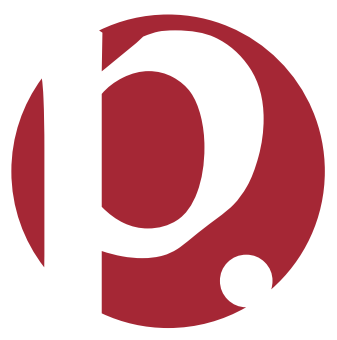

